\title{
Predicting nutritional requirements and lactation performance of dual-purpose cows using a dynamic model
}

\author{
O. Reynoso-Campos ${ }^{\text {a }}$, D.G. Fox ${ }^{\text {a }}$, R.W. Blake ${ }^{\text {a,*, }}$, \\ M.C. Barry ${ }^{\text {a }}$, L.O. Tedeschi ${ }^{\text {a }}$, C.F. Nicholson ${ }^{\text {b, }}$ \\ H.M. Kaiser ${ }^{\text {b }}$, P.A. Oltenacu ${ }^{\text {a }}$ \\ a Departments of Animal Science, Cornell University, 131 Morrison Hall, Ithaca, NY 14853, USA \\ b Applied Economics and Management, Cornell University, Ithaca, NY 14853, USA
}

\begin{abstract}
A dynamic application of the Cornell Net Carbohydrate and Protein System (CNCPS) model was developed to predict annual cycles in animal nutrient requirements and performance of dual-purpose (milk and beef) cows. Interactions from mobilisation and repletion of body tissue reserves and feed biological values are accounted with a time step of one day, which considers physiological status of the animal, variation in dietary composition, and other environmental factors. This outcome was achieved by modifying the input and output structure of the CNCPS version 4.0 to compute body weight and changes in body reserves based on predicted milk production, intake of feed dry matter, and energy balance. The supply of metabolisable energy from dietary intake is supplemented by tissue mobilised to support milk synthesis in early lactation; body tissue is repleted when energy balance is positive. Predicted animal nutrient requirements, milk production, dry matter intake, and changes in body weight and body condition score over the reproductive cycle were consistent with patterns and values in published reports and field observations in the Gulf Coast of Mexico case study region. Our simulations showed that a dynamic application of the CNCPS facilitates more accurate monitoring and management of cyclic changes in energy and protein balances over the calving interval of dual-purpose cows, which can help producers to achieve productivity and profitability goals.
\end{abstract}




\section{Introduction}

Farm resource strategies that are sensitive to annual cycles in animal requirements and to interactions with body tissue reserves are required to better exploit dualpurpose cattle productivity potentials in Latin America. Nutrition is a key component that must be accurately accounted for in designing improved dual-purpose cattle systems. Animal nutrient requirements, feed biological values, and expected animal performance must be accurately predicted. Our previous work (Nicholson et al., 1994a,b, 1995; Rueda et al., 2003) demonstrated that nutrition is a biological fulcrum of dual-purpose system productivity, where appropriate animal grouping and feeding strategies are needed to manage whole-farm profitability. Managers must consider variation in supply and quality of feedstuffs, animal requirements and feed biological values to optimise diets to achieve productivity goals (Fox et al., 1995; Juarez et al., 1999; Nicholson et al., 1994a; Reyes et al., 1981). Animal requirements and nutrient utilization vary widely depending on breed, feeds, management practices, and environmental and economic conditions (Fox et al., 1997, 2000).

The system most often used to evaluate feeding systems under tropical conditions is the National Research Council $(1989,2001)$. When this system is applied to tropical conditions, cattle performance is misrepresented because the equations and methods were developed empirically for temperate (and affluent) situations (Juarez et al., 1999; Tedeschi et al., 2002a,b). Additionally, this system is static, and was developed to predict animal requirements and nutrients consumed for a particular amount of milk. The Cornell Net Carbohydrate and Protein System (CNCPS) model uses mechanistic approaches that permit prediction of cattle requirements and the supply of nutrients in temperate and tropical environments, but is static because its input and output structure is designed to give predictions for specific body weights, body condition scores, and amounts of milk (Fox et al., 2003). A systematic basis for predicting nutrient requirements for management groups of cows and production circumstances requires accounting for interdependent periods of negative and positive energy balance during a calving interval (Reyes et al., 1981; Williams et al., 1989). Accounting for body tissue nutrient turnover can improve animal and economic performance over time by avoiding low milk yield, delayed conception and extended calving interval, and low body weight of calves at weaning (Canfield and Butler, 1991; Ventura and Ozuna, 1995). These outcomes depend on the degree to which an animal's nutrient requirements are satisfied. Factors affecting the accuracy of estimated requirements of metabolisable energy (ME) include (1) accounting for changes in body weight and body composition over time instead of a constant body weight and (2) considering daily estimates instead of averages of static estimates for discrete intervals of the production cycle.

Therefore, management would be aided by a more accurate assessment of requirements and sources of nutrients for target scenarios and groups of animals that depict nutritional status and performance over time. Managers would be assisted in evaluating current and expected animal performance by monitoring corresponding production deviations for specific groups of cows, determining probable causes, and 
deciding corrective or preventive measures to improve the utilisation of inputs. Table 1 provides a contextual summary of key nutritional constraints, and strategies for alleviating them, on the performance of dual-purpose cattle systems in tropical regions.

Accordingly, our first objective is to describe a dynamic application of the CNCPS model that was developed to account for the cyclical changes in energy and protein tissue balances that occur during the reproductive cycle of dual-purpose cows in tropical production situations. Our second objective is to demonstrate the use of this dynamic application of the CNCPS model in evaluating dual-purpose cow performance over the reproductive cycle in specific production situations. In particular, we simulate scenarios that provide a benchmark for the dynamic behaviour of nutrient balances, and illustrate the importance of accounting for tissue mobilisation and repletion in predictions of animal nutrient requirements.

\section{The Cornell Net Carbohydrate and Protein System model}

The CNCPS is a deterministic model that integrates empirical and mechanistic methods to predict animal requirements, nutrients that can be derived from feeds, and animal performance on a selected day during a production cycle (Fox et al., 1995, 2003). This nutrition model comprises physiological and metabolic components that describe ruminal carbohydrate fermentation and protein degradation, feed intake, intestinal digestion, absorbed nutrients and their partitioning for tissue maintenance and growth, pregnancy, nutrient excretion (milk), and heat production. The CNCPS model has been evaluated for its ability to predict animal performance from the diet consumed; the model accounted for $90 \%$ of the variation in milk production with a bias of 1.3\% (Fox et al., 2003). The CNCPS has been evaluated in various tropical production situations including Brazil (Lanna et al., 1996; Rueda et al., 2003), Honduras (Traxler, 1997), and the Gulf coastal region of Mexico (Juarez et al., 1999) using repeated independent static predictions of dietary adequacy and animal response during the production cycle. Previous versions of the CNCPS model were used to obtain technical coefficients on specified days of a calving interval for a linear programming model of optimal profitability for dual-purpose cattle systems (Nicholson et al., 1994a,b). Thus, the CNCPS has been adequately validated for static situations, and constitutes an appropriate tool for dynamic simulation.

Previous applications of the CNCPS were for scenarios with invariant body weight and body condition (subcutaneous adipose tissue reserves) throughout a cow's production cycle. The impacts of an animal's physiological status on nutrient requirements and supplies were ignored. Evaluation based on static prediction ignores cumulative effects of distinctly different patterns over time for daily dry matter intake, milk production, body weight, and body tissue balances of metabolisable energy (ME) and metabolisable protein (MP) or its indicator, body condition score. Correct accounting of these biological interactions with a dynamic method can improve forecasting and management of cattle systems. 
Table 1

Nutritional constraints and strategies for intensifying dual-purpose cattle systems in the tropics

\begin{tabular}{|c|c|c|}
\hline Constraint on intensification from improved nutrition & Strategy or information required to address constraint & References \\
\hline $\begin{array}{l}\text { Define dynamic farm resource strategy and animal } \\
\text { response targets } \\
\text { - Access market growth in animal products }\end{array}$ & $\begin{array}{l}\text { - Obtain seasonal market prices, costs and supplies } \\
\text { - Allocate resources to achieve marketing goals } \\
\text { - Dietary nutrients, feeds, land, labor, capital } \\
\text { - Technology in dietary management }\end{array}$ & $\begin{array}{l}\text { Avila (1995) } \\
\text { Gonzalez (1993) } \\
\text { Delgado et al. (1999) } \\
\text { Nicholson et al. (1995) }\end{array}$ \\
\hline $\begin{array}{l}\text { Define optimal (e.g., maximum profit) nutrition for } \\
\text { animal groups over time } \\
\text { - Plan to achieve annual (seasonal) production goals }\end{array}$ & $\begin{array}{l}\text { - Ascertain biological values for available feeds } \\
\text { - Estimate supplies and quality of feedstuffs and } \\
\text { dietary potentials by season of the year } \\
\text { - Accurately predict dietary requirements for } \\
\text { growth, lactation, tissue repletion and gestation }\end{array}$ & $\begin{array}{l}\text { Juarez et al. (1999) } \\
\text { Fox et al. (1995) } \\
\text { Tedeschi et al. (2002a,b) }\end{array}$ \\
\hline $\begin{array}{l}\text { Formulate diets for productivity goals considering feed } \\
\text { biological values and animal nutrient requirements } \\
\text { - Feed biological values, requirements and nutrient } \\
\text { use efficiencies vary with physiological status, } \\
\text { dietary composition, breed, feeds, and management } \\
\text { environment }\end{array}$ & $\begin{array}{l}\text { - Accurately predict animal requirements } \\
\text { (tabular systems are inaccurate) } \\
\text { - Estimate nutrient requirements for target performance } \\
\text { of animal groups and production conditions }\end{array}$ & $\begin{array}{l}\text { Fox et al. }(1997,2000) \\
\text { Nicholson et al. }(1994 a) \\
\text { Tedeschi et al. }(2002 b)\end{array}$ \\
\hline $\begin{array}{l}\text { Maintenance requirements vary with changes in body weight } \\
\text { - Energy and protein available for production depends on } \\
\text { the proportion needed for maintenance }\end{array}$ & $\begin{array}{l}\text { - Determine animal nutrient requirements for body } \\
\text { weight which fluctuate with lactation (typically ignored) } \\
\text { - Explicitly account for tissue nutrient reserves as an } \\
\text { input to herd and farm productivity }\end{array}$ & $\begin{array}{l}\text { Fox et al. (2000) } \\
\text { Williams et al. (1989) }\end{array}$ \\
\hline
\end{tabular}


Table 1 (continued)

\begin{tabular}{|c|c|c|}
\hline Constraint on intensification from improved nutrition & Strategy or information required to address constraint & References \\
\hline \multicolumn{3}{|l|}{$\begin{array}{l}\text { Body tissue balance must be managed long term to achieve } \\
\text { farm productivity goals }\end{array}$} \\
\hline $\begin{array}{l}\text { - Energy balance affects reproduction: positive energy } \\
\text { balance predisposes ovulation postpartum }\end{array}$ & $\begin{array}{l}\text { - Specify physiological interdependency of stages of } \\
\text { negative and positive energy balance throughout } \\
\text { repeated production cycles (calving intervals) }\end{array}$ & $\begin{array}{l}\text { Canfield and Butler (1991) } \\
\text { Fox et al. (1992) } \\
\text { Nicholson et al. (1994b) }\end{array}$ \\
\hline $\begin{array}{l}\text { - Explicit accounting of ME and MP balance quantifies } \\
\text { tissues mobilised and repleted }\end{array}$ & $\begin{array}{l}\text { - Energy balance accounting corroborated by a condition } \\
\text { score more accurately monitors tissue reserves than } \\
\text { body condition alone }\end{array}$ & Reyes et al. (1981) \\
\hline $\begin{array}{l}\text { Determine reference, or expected, performance of } \\
\text { management groups by monitoring their production } \\
\text { deviations to guide preventive or corrective measures }\end{array}$ & $\begin{array}{l}\text { - Systematically predict performance throughout calving } \\
\text { interval (reference curves) and periodically diagnose } \\
\text { dietary adequacy and productivity of cow groups } \\
\text { - Identify low farm resource use potentials and determine } \\
\text { management actions }\end{array}$ & $\begin{array}{l}\text { Fox et al. (2000) } \\
\text { Nicholson et al. (1994b) } \\
\text { Reyes et al. (1981) }\end{array}$ \\
\hline
\end{tabular}




\subsection{Need for a dynamic application of the CNCPS model}

Body composition of cows under consideration in the CNCPS model v. 4.0 (Fox et al., 2000) corresponds to a standard reference body weight of $400 \mathrm{~kg}$ containing $22 \%$ fat on an empty weight basis (Lanna et al., 1996; Fox et al., 1997, 2000). Dry matter intake prediction equations reflect the observed consumption of tropical forages by lactating cows (Traxler, 1997) and environmental effects (Fox and Tylutki, 1998). Nutrient requirements of Zebu cows include energy for body maintenance that varies with milking potential (National Research Council, 2000). The library of available feeds includes chemical composition and rates of digestion of carbohydrate and protein fractions for common forages and by-products in tropical Latin America (Juarez et al., 1999; Tedeschi et al., 2002a; Traxler, 1997). The available neutral detergent fibre (fermentable plant cell wall constituents) digestion rates are from forages in the Gulf region of Mexico (Juarez et al., 1999).

The CNCPS model has been used to obtain static predictions of nutritional requirements, lactation performance, and physiological status on selected days during a cow's calving interval. In practice, accurate assessments require user experience to correctly approximate an animal's body weight and body condition score. However, the lack of prior information about the amounts of body tissues already mobilised, and those remaining, to support current milk production, and correct repletion requirements for the next lactation precludes efficacious management. Insufficient repletion of tissue reserves reduces lactation and reproductive performance whereas accumulating excess tissue reserves can reduce profitability. Reyes et al. (1981) showed economic payoffs from optimal schedules of tissue repletion.

\subsection{Dynamic application of the CNCPS model}

An input and output structure was developed for the CNCPS model v. 4.0 to account for pertinent changes throughout calving interval in daily milk production, daily mobilisation or repletion of body tissues, body tissue balance in stores of energy and protein, dietary requirements of ME and MP, and feed biological values of dietary ingredients. Predicted values for each day of a cow's calving interval (production cycle) were updated sequentially. Outputs from one evaluation were inputs for the next day's evaluation after accounting for tissue reserves that were mobilised or repleted. The dynamics of how energy balances are translated into tissue mobilisation and repletion are represented by these key relationships:

$$
\begin{aligned}
& \text { AdiposeTissue }_{t}=\text { AdiposeTissue }_{t-1}+\mathrm{MEB}_{t-1} \cdot \theta_{M, R}^{\text {AdiposeTissue },} \\
& \mathrm{BW}_{t}=\mathrm{BW}_{t-1}+\mathrm{MEB}_{t-1} \cdot \theta_{M, R}^{\mathrm{BW}}, \\
& \mathrm{MPT}_{t}=\left(\mathrm{BW}_{t}-\mathrm{BW}_{t-1}\right) \cdot \theta_{M, R}^{\mathrm{MP}},
\end{aligned}
$$

where $\mathrm{MEB}=\mathrm{ME}$ balance, the $\theta$ are transformation coefficients for tissue mobilization $(M)$ and repletion $(R), \mathrm{BW}=$ cow body weight, and MPT indicates the 
amount of MP available from tissue mobilisation. It is assumed that energy balances are accurately translated directly into changes in the amounts of adipose tissue and BW with a single linear parameter, that MEB is calculated based on exogenous milk production (i.e., not constrained by available energy or protein). The composition of mobilised or repleted tissue is computed as described by Fox et al. (2000).

Fig. 1 summarizes this process, which is initialised at parturition with descriptions of animal, environmental, and feed characteristics (Table 2). Animal requirements for maintenance, gestation, lactation, growth and tissue reserves were predicted as described by Fox et al. (2000). Feed biological values for animal groups were estimated from feed chemical composition (e.g., dry matter, neutral detergent fibre, crude protein and its solubility) and rates of digestion (of carbohydrate and protein fractions) as shown in Table 3. Pool sizes of carbohydrate and protein fractions and the corresponding rumen microbial growth were predicted as described by Sniffen et al. (1992) and Russell et al. (1992). The empirical equation to estimate MP requirements for maintenance as adopted by the National Research Council (2000) for beef cattle (3.8 $\mathrm{g}$ MP kg-1 metabolic body weight) was used instead of the factorial approach (Fox et al., 2000).

These dietary pools describe the nutrients available for lactation, gestation and growth after meeting body maintenance requirements and accounting for the amounts of body tissues mobilised or repleted. When intake of dietary energy exceeds total requirements, adipose tissue reserves increase by the amount in excess times the partial efficiency of its use for repletion, which is greater in lactating $(75 \%)$ than in non-lactating cows $(60 \%)$. If energy is deficient, body reserves support lactation according to the partial efficiency of mobilising adipose tissue for milk synthesis. Energy balance determines changes in body weight and tissue reserves (condition score). Daily milk production is updated following characteristic response for a specified milking potential (e.g., 2500 or $3500 \mathrm{~kg}$ in a complete lactation; Fox et al., 2000) using predicted intake of dietary nutrients and nutrient yield from

Planning and monitoring tool

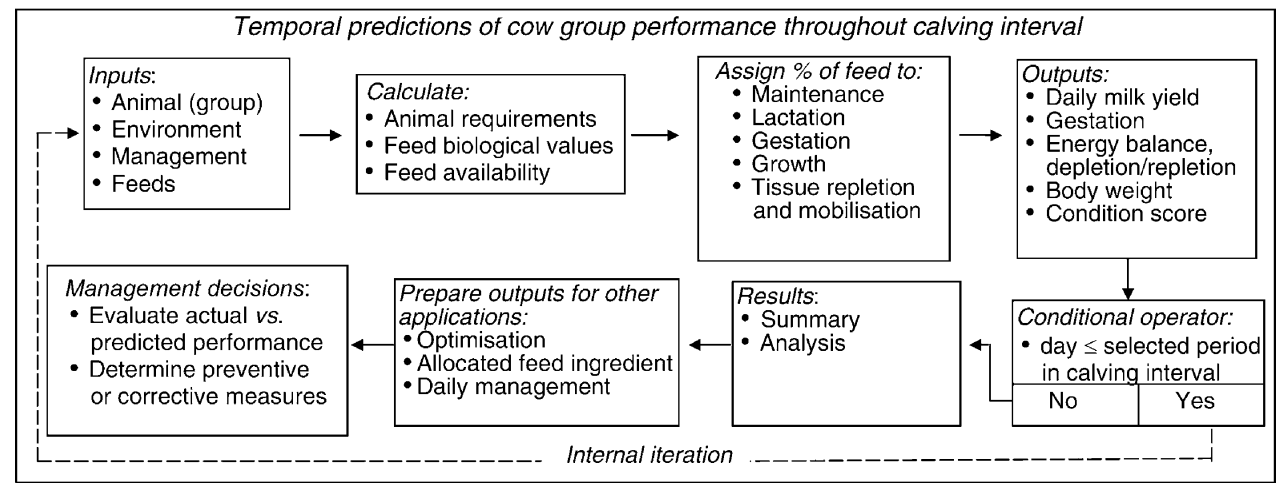

Fig. 1. Schematic representation of the dynamic version of the Cornell Net Carbohydrate and Protein System model for planning and monitoring daily cow performance and body tissue reserves throughout a calving interval. 
Table 2

Animal and environmental descriptions to evaluate dietary potentials and animal performance

\begin{tabular}{|c|c|c|}
\hline Variable & Value $^{a}$ & Units \\
\hline \multicolumn{3}{|l|}{ Animal } \\
\hline Animal type & 2 & Lactating dairy cow \\
\hline Age & 65 & Months \\
\hline Body weight ${ }^{\mathrm{b}}$ & 470 & $\mathrm{~kg}$ \\
\hline Breed type & 1 & Beef $\times$ dairy \\
\hline Mature weight & 470 & $\mathrm{~kg}$ at maturity \\
\hline Condition score & $3^{\mathrm{b}}$ & $1-5$ \\
\hline Breeding system & 2 & 2-way cross \\
\hline Dam breed & $\ldots$ & Brahman \\
\hline Dam's maternal & $\ldots$ & Holstein \\
\hline Dam's paternal & $\ldots$ & Brahman \\
\hline Dam mother sire & $\ldots$ & Brahman \\
\hline Dam mother dam & $\ldots$ & Brahman \\
\hline Days pregnant & 0 & Days \\
\hline Days since previous calving ${ }^{\mathrm{b}}$ & 420 & Days \\
\hline Lactation number & 2 & Number \\
\hline Rolling herd average (dairy) & 2500 & $\mathrm{~kg}$ lactation $^{-1}$ \\
\hline Milk production (dairy) ${ }^{\mathrm{b}}$ & 11.5 & $\mathrm{~kg} \mathrm{day}^{-1}$ \\
\hline Milk fat (dairy) & 4.1 & $\%$ \\
\hline Milk protein (dairy) & 3.9 & $\%$ \\
\hline Expected calf birth weight & 31.5 & $\mathrm{~kg}$ \\
\hline \multicolumn{3}{|l|}{ Environmental factors } \\
\hline Wind speed & 1 & $\mathrm{kph}$ \\
\hline Previous temperature & 26 & ${ }^{\circ} \mathrm{C}$ \\
\hline Current temperature & 26 & ${ }^{\circ} \mathrm{C}$ \\
\hline Storm exposure & 2 & Yes \\
\hline Night cooling & 2 & Yes \\
\hline Hair depth & 1.5 & $\mathrm{~cm}$ \\
\hline Hide & 1 & Thin \\
\hline Hair coat & 1 & No mud \\
\hline Cattle panting & 1 & None \\
\hline
\end{tabular}

${ }^{\text {a }}$ Values based on Castañeda et al. (1993).

${ }^{\mathrm{b}}$ Values change in accordance with day of lactation.

mobilised tissues. In agreement with available data, weight gain and loss after maturity predicted by the body reserves sub-model is similar in content of energy and protein in weight gain during growth, and is a function of current body weight, condition score, and daily gain or loss of body weight (NRC, 2000). Animal requirements and availability of ME and MP, feed biological values, dry matter intake, milk production, body weight, expected body condition score, and associated tissue balances of ME and MP are calculated and stored. As described above, predicted values become inputs for the next day's evaluation if the day under consideration precedes the end of the productive cycle (e.g., next calving date). Otherwise, internal iteration stops and outputs are summarised. Performance and underlying nutritional relationships depend on the pattern of daily predictions. 


\subsection{Evaluation of the dynamic application of the CNCPS model}

Animal performance for a typical Gulf coast of Mexico grazing scenario was simulated for mature Bos taurus (Holstein) $\times$ Bos indicus (Brahman) cows yielding 2500 $\mathrm{kg}$ milk in a 270-day lactation with a calving interval of 420 days (Castañeda et al., 1993). Table 2 summarizes the animal and environmental descriptions used to represent dual-purpose cow production systems in the Gulf coastal region of Mexico. Lactating cows typically graze forage and are fed about $2 \mathrm{~kg}$ of a commercial supplement containing $16 \%$ crude protein, and produce milk containing about $3.9 \%$ milk fat and $4.1 \%$ protein (Castañeda et al., 1993). Non-lactating (dry) cows typically consume only grazed forage.

Milk production on a particular day of lactation was computed based on the total annual milk yield and day of lactation, using equations that describe the lactation

Table 3

Chemical composition and rates of digestion for fertilized (lactating cows) and unfertilized (dry cows) African Star grass (Cynodon plectostachyus) at 45 days regrowth and commercial supplement ${ }^{\text {a }}$

\begin{tabular}{|c|c|c|c|c|}
\hline \multirow[t]{2}{*}{ Variable } & \multirow[t]{2}{*}{ Units } & \multicolumn{2}{|c|}{ Cynodon plectostachyus } & \multirow{2}{*}{$\begin{array}{l}\text { Commercial } \\
\text { supplement }\end{array}$} \\
\hline & & Lactating & Dry & \\
\hline \multicolumn{5}{|l|}{ Composition } \\
\hline Dry matter & $\% \mathrm{AF}^{\mathrm{b}}$ & 21.4 & 32.4 & 89.8 \\
\hline NDF & $\% \mathrm{DM}$ & 71.6 & 78.3 & 20.5 \\
\hline Effective NDF & $\% \mathrm{NDF}$ & 41.0 & 41.0 & 46.4 \\
\hline Crude protein & $\% \mathrm{DM}$ & 10.0 & 6.6 & 16.3 \\
\hline CP solubility & $\% \mathrm{CP}$ & 35.7 & 28.4 & 15.8 \\
\hline $\mathrm{ADFIP}^{\mathrm{c}}$ & $\% \mathrm{CP}$ & 8.0 & 13.1 & 5.8 \\
\hline Fat & $\% \mathrm{DM}$ & 1.6 & 1.1 & 1.2 \\
\hline Ash & $\% \mathrm{DM}$ & 11.0 & 7.9 & 13.5 \\
\hline Starch & $\% \mathrm{NSC}^{\mathrm{d}}$ & 22.6 & 28.0 & 90.0 \\
\hline Lignin & $\% \mathrm{DM}$ & 7.3 & 7.6 & 18.0 \\
\hline $\mathrm{NPN}^{\mathrm{e}}$ & $\% \mathrm{SOLP}^{\mathrm{f}}$ & 40.1 & 36.5 & 32.3 \\
\hline NDFIP & $\% \mathrm{CP}$ & 34.0 & 43.3 & 8.0 \\
\hline \multicolumn{5}{|l|}{ Digestion rates } \\
\hline Sugars & $\% / h$ & 13.2 & 13.1 & 160.0 \\
\hline Starch & $\% / h$ & 13.2 & 13.1 & 20.0 \\
\hline Available NDF & $\% / h$ & 7.0 & 5.0 & 11.0 \\
\hline \multicolumn{5}{|l|}{ True protein } \\
\hline Fast & $\% / h$ & 135.0 & 135.0 & 155.0 \\
\hline Medium & $\% / h$ & 11.0 & 11.0 & 14.0 \\
\hline Slow & $\% / h$ & 5.3 & 5.2 & 0.1 \\
\hline
\end{tabular}

${ }^{a}$ Juarez et al. (1999).

${ }^{\mathrm{b}}$ As-fed basis.

${ }^{\mathrm{c}}$ Acid detergent fibre insoluble protein.

${ }^{\mathrm{d}}$ Non-structural carbohydrates.

${ }^{\mathrm{e}}$ Non-protein nitrogen.

${ }^{f}$ Soluble protein.

${ }^{\mathrm{g}}$ Neutral detergent fibre insoluble protein. 
curve (Fox et al., 1992). Total dry matter intake for a particular day in milk was computed with the equations of Traxler (1997), which accounts for the effects of body weight, milk production and neutral detergent fibre content of forage. Dry matter intake (DMI) from pasture was computed as total DMI minus supplement DMI, which assumes that forage availability permits maximum voluntary intake. No supplement was fed when cows were not lactating (i.e., during the dry period). The forage composition on a particular day of the reproductive cycle was based on fertilised and unfertilised Cynodon plectostachyus being fed to cows during lactation and the dry period, respectively (Table 3). Body weights to compute maintenance requirements and DMI on a particular day of the reproductive cycle were adjusted for weight gains and losses during the reproductive cycle. Body weights at parturition averaged $470 \mathrm{~kg}$ with a body condition score of 3 (1-5 scale). Daily weight loss during negative energy balance averaged $0.35 \mathrm{~kg}$, which was predicted to occur by day 115 of lactation. Gains in adipose tissue reserves (positive energy balance) occurred from days 116 to 270 of lactation. Full repletion of body tissue reserves is management that limits deleterious effects on animal reproduction and subsequent lactation (Reyes et al., 1981). The data used for these simulations are consistent with other data reported for Latin American conditions (Table 4).

Table 4

Characteristics and production parameters of dual-purpose cattle farms in the Gulf coast region of Mexico and in other Latin American countries

\begin{tabular}{|c|c|c|c|}
\hline \multirow[t]{2}{*}{ Variable } & \multirow{2}{*}{$\frac{\text { Mexico }}{\text { Value }}$} & \multicolumn{2}{|c|}{ Other Latin America $^{\mathrm{a}}$} \\
\hline & & Minimum & Maximum \\
\hline Age at first calving, mo & $\ldots$ & $31 .^{\mathrm{c}}$ & 36. \\
\hline Body weight (calving), $\mathrm{kg}$ & 470. & 420. & 550. \\
\hline Calving rate, $\%$ of total cows in herd & 71. & $45 .^{\mathrm{b}}$ & 85. \\
\hline Days open & 150. & 120. & 222 b $^{b}$ \\
\hline Calving interval & 420. & 374. & $568 .^{\mathrm{b}}$ \\
\hline \multicolumn{4}{|l|}{ Mortality, \% } \\
\hline$<1$ year & 7.5 & 5.0 & $8.0^{\mathrm{d}}$ \\
\hline$>1$ year & 1.0 & 1.0 & $1.5^{\mathrm{d}}$ \\
\hline Culled cows, $\%$ year $^{-1}$ & 20. & $15^{\mathrm{d}}$ & $20 .^{d}$ \\
\hline Period of negative energy balance, days & $115 .^{\mathrm{e}}$ & $\ldots$ & $\ldots$ \\
\hline Marketable milk yield, kg per cow day ${ }^{-1}$ & 6.6 & 4.0 & $10.0^{\mathrm{f}}$ \\
\hline Lactation, days & 270. & 212. & $330 .^{f}$ \\
\hline Dry period, days & 150. & 104. & $238 .^{f}$ \\
\hline Milk per lactation, $\mathrm{kg}$ & 2500.0 & 1000.0 & $3000.0^{\mathrm{f}}$ \\
\hline Stocking rate, $\mathrm{AU}^{\mathrm{g}} \mathrm{ha}^{-1}$ & 1.4 & 0.8 & $4.1^{\mathrm{f}}$ \\
\hline
\end{tabular}

${ }^{a}$ Honduras, Costa Rica, Panama, Bolivia, Colombia, Brazil, and Venezuela from Sere and Vaccaro (1985) and Nicholson et al. (1994a).

${ }^{\mathrm{b}}$ Enriquez and Kanahan (1991).

${ }^{\mathrm{c}}$ Muñoz et al. (1990).

${ }^{\mathrm{d}}$ Castañeda et al. (1993).

${ }^{\mathrm{e}}$ As determined by the Cornell Net Carbohydrate and Protein System.

${ }^{f}$ Gonzalez (1993).

${ }^{\mathrm{g}} \mathrm{AU}$ refers to an animal unit weighing $450 \mathrm{~kg}$. 
Results were compared to biologically attainable expectations for dual-purpose systems (Nicholson et al., 1994a,b; Sere and Vaccaro, 1985) and to field observations from the Gulf coastal region of Mexico. Selected CNCPS static predictions were compared to those from the dynamic application of the model to examine the discrepancies from ignoring tissue balance and turnover during lactation (periods of negative and positive energy balance) and the dry period (positive energy balance).

\section{Evaluation of predictions from the dynamic application of the CNCPS model}

Reference curve predictions for milk production, dry matter intake, ME and MP balances, body weight and condition score are in Fig. 2. Maximum dietary consumption occurs about two weeks after peak daily milk production (Fig. 2(a)), consistent with expectations. Average dry matter intake (Table 5) during negative energy balance is $12.1 \mathrm{~kg}$, or about $2.7 \%$ of body weight. As a result of using the DMI equation of Traxler (1997) developed for dual-purpose cows fed tropical forages, this
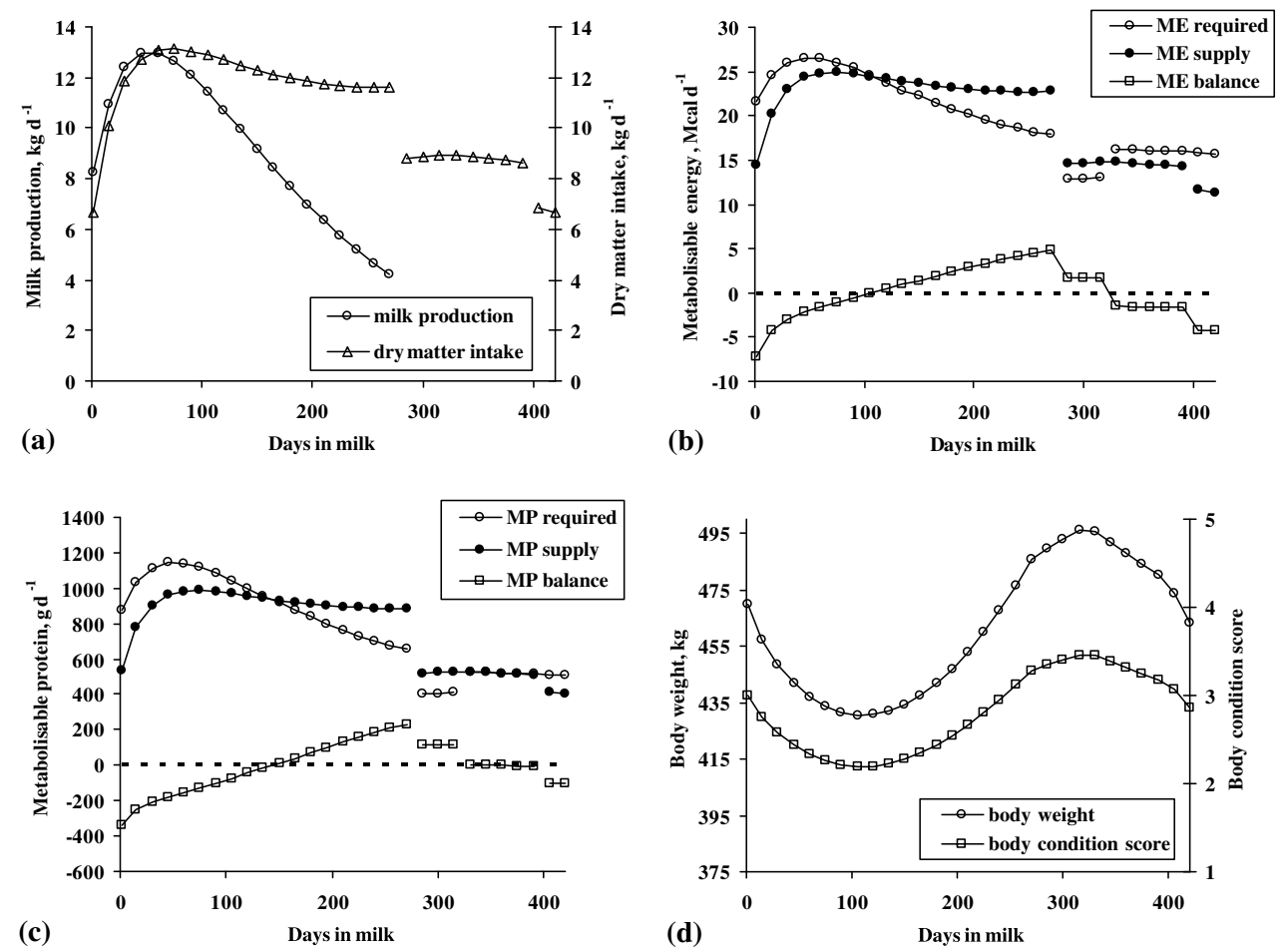

Fig. 2. Example reference curves for management groupings of dual-purpose cows producing $2500 \mathrm{~kg}$ milk in a 270-day lactation with a calving interval of 420 days. (a) Shows predicted responses in milk production and dry matter intake; (b) shows metabolisable energy requirements, metabolisable energy supply, and energy balance; (c) shows metabolisable protein requirements, metabolisable protein supply, and protein balance; and (d) shows body weight and body condition score throughout lactation and the dry period. 
Table 5

Average values for body weights, daily gain or loss in body weight, body condition score, dry matter intake, and milk yields of dual-purpose cows in negative energy balance, positive energy balance, and dry periods as simulated by the dynamic version of the Cornell Net Carbohydrate and Protein System model 4.0 compared with corresponding field values observed in the Gulf coastal region of Mexico

\begin{tabular}{|c|c|c|c|}
\hline \multirow[t]{2}{*}{ Variable } & \multirow[t]{2}{*}{ CNCPS predictions } & \multicolumn{2}{|c|}{ Regional Gulf of Mexico values } \\
\hline & & Minimum & Maximum \\
\hline \multicolumn{4}{|l|}{ Negative energy balance } \\
\hline \multicolumn{4}{|l|}{ Lactating cows, day 0 to $115^{\mathrm{a}}$} \\
\hline Average body weight (BW), $\mathrm{kg}$ & 435.0 & 400.0 & $550.0^{\mathrm{b}}$ \\
\hline Average daily loss, $\mathrm{g}$ day $^{-1}$ & -410.0 & -160.0 & -800.0 \\
\hline Average body condition score ${ }^{c}$ & 2.3 & 2.0 & $2.5^{\mathrm{d}}$ \\
\hline Dry matter intake (DMI), $\mathrm{kg} \mathrm{day}^{-1}$ & 12.0 & $\ldots$ & $\ldots$ \\
\hline DMI, $\%$ of BW & 2.7 & $\ldots$ & $\ldots$ \\
\hline Milk yield, $\mathrm{kg}$ day $^{-1}$ & 11.9 & 3.0 & 12.0 \\
\hline \multicolumn{4}{|l|}{ Positive energy balance } \\
\hline \multicolumn{4}{|l|}{ Lactating cows, day 116 to $270^{\mathrm{e}}$} \\
\hline Average BW, kg & 434.0 & 400.0 & $550.0^{\mathrm{b}}$ \\
\hline Average daily gain, $\mathrm{g} \mathrm{day}^{-1}$ & 227.0 & 100.0 & 700.0 \\
\hline Average body condition score ${ }^{\mathrm{c}}$ & 2.6 & 2.0 & $3.0^{\mathrm{d}}$ \\
\hline DMI, $\mathrm{kg} \mathrm{day}{ }^{-1}$ & 11.6 & $\ldots$ & $\ldots$ \\
\hline DMI, $\%$ of BW & 2.7 & $\ldots$ & \\
\hline Milk yield, $\mathrm{kg} \mathrm{day}^{-1}$ & 7.0 & 3.0 & 11.0 \\
\hline \multicolumn{4}{|l|}{ Dry cows, day 271 to $420^{\mathrm{f}}$} \\
\hline Average BW, kg & 477.0 & 450.0 & $500.0^{\mathrm{g}}$ \\
\hline Average daily gain, $\mathrm{g} \mathrm{day}^{-1}$ & 65.0 & 0.0 & 800.0 \\
\hline Average body condition score & 2.8 & 2.5 & $3.5^{\mathrm{d}}$ \\
\hline DMI, kg day ${ }^{-1}$ & 8.3 & $\ldots$ & $\cdots$ \\
\hline DMI, $\%$ of BW & 1.7 & $\ldots$ & $\ldots$ \\
\hline
\end{tabular}

${ }^{\text {a }}$ Period when cows support milk synthesis by catabolising body tissues.

${ }^{\mathrm{b}}$ Avila (1995).

${ }^{\mathrm{c}}$ Scale of $1-5$ units.

${ }^{\mathrm{d}}$ Villa-Godoy and Arreguin (1993), personal communication.

${ }^{\mathrm{e}}$ Lactating animals gaining weight (in positive energy balance).

${ }^{\mathrm{f}}$ Non-lactating animals in positive energy balance.

${ }^{\mathrm{g}}$ Castañeda et al. (1993).

predicted feed consumption is approximately $20 \%$ higher than predicted with the NRC (1989) equations developed for lactating dairy cows fed temperate feeds.

Cows in early lactation with negative energy balance ( $\leqslant 115$ days in milk) mobilise about 2.1 Mcal ME day ${ }^{-1}$ (a total of 239 Mcal ME for this period) when total requirements average $25.4 \mathrm{Mcal} \mathrm{ME} \mathrm{day}^{-1}$ and average daily intake is $23.3 \mathrm{Mcal}$ ME. As shown in Fig. 2(d), lactation in this initial stage is supported with energy for lactation from $40 \mathrm{~kg}$ of body weight loss. These losses are about half as much as has been measured, for example, in Brahman cows eating Panicum maximum in the lowlands of Venezuela (Neidhardt et al., 1979).

A deficiency in dietary availability of MP accompanies the period of negative energy balance (164 $\mathrm{g} \mathrm{day}^{-1}$; Fig. 2(c)). Recommendations for dairy cattle assume 
$256 \mathrm{~g}$ of absorbed protein are derived per kilogram of body weight loss during lactation (National Research Council, 2001). Therefore, in our case $0.35 \mathrm{~kg} \mathrm{day}^{-1}$ of weight loss is expected to yield about one half $\left(90 \mathrm{~g} \mathrm{day}^{-1}\right)$ of the predicted MP deficit, which indicates insufficient total protein to support lactation. This discrepancy indicates the need for further research to accurately account for protein metabolism and body protein mobilisation in early lactation. At least part of this under-prediction of MP balance is from assuming a static efficiency of $65 \%$ for MP use for lactation. Reports in the literature (NRC, 2001; Ruiz et al., 2002) indicate MP efficiency for lactation can be as much as $75 \%$ when dietary protein intake is below requirements.

Simulated body weights (Fig. 2(d)) are within the range of observation in the case study region (Avila, 1995; Castañeda et al., 1993; Table 5). By day 116 of lactation, cows are predicted to have achieved positive energy balance and to weigh about 430 $\mathrm{kg}$ and reached $470 \mathrm{~kg}$ by day 245 . This rate of tissue repletion $\left(310 \mathrm{~g} \mathrm{day}^{-1}\right)$ is less than the $421 \mathrm{~g} \mathrm{day}^{-1}$ reported by Juarez et al. (1999) for mature crossbred cows (3/4 Holstein $\times 1 / 4 \mathrm{Zebu})$ in mid-lactation consuming high quality forage in southeastern Mexico. Conception is assumed to occur near 140 days in lactation in accordance with the extended postpartum anoestrus resulting from the energy deficit.

Average dry matter intake after 115 days is similar to the amount consumed at about 50 days. During the dry period intake is reduced due to growth of the conceptus (Fig. 2(b)). This trend is maintained until about day 400 when conceptus mass and uterine expansion restrict dietary intake. By the end of the reproductive cycle (day 420), animals are at beginning body weight $(470 \mathrm{~kg}$ ) with a full complement of tissue reserves to initiate and support a new reproductive cycle. Metabolisable protein balance (Fig. 2(c)) averaged 15\% below requirement during the first 115 days, which is similar to that reported by Nicholson et al. (1994a) for the same type of animals and similar diet.

Body condition scores are computed from ME balances (Fox et al., 2000, 2003). These predicted changes in body nutrient stores are similar to those in other reports where condition scores of lactating cows are used to evaluate energy balance, rate of tissue mobilisation, and to manage lactation and reproductive performance (Mulvany, 1981; Otto et al., 1991; Villa-Godoy and Arreguin, 1993). The dynamic application of the CNCPS model also provided detailed nutritional information to help assess dietary potential and animal performance throughout the calving interval (e.g., energy and protein requirements for maintenance, growth, lactation and pregnancy, energy cost of excreting excess nitrogen as urea, recycled nitrogen, peptides and rumen nitrogen balance, rumen microbial yield).

These reference curves (Fig. 2) represent aggregated considerations about requirements for body maintenance, lactation, pregnancy, and body tissue reserves. Discontinuities reflect the abrupt drop in requirements with the end of lactation (day 271), and higher requirements (about day 320) from escalating growth of the conceptus.

Fig. 3 illustrates the potential errors in not accounting for body tissue dynamics to predict the potential milk production. In this evaluation, the dynamic application of the CNCPS model accounted for the typical amount of ME provided by mobilised body reserves to support homeorrhetic (physiologically orchestrated) drive in early 


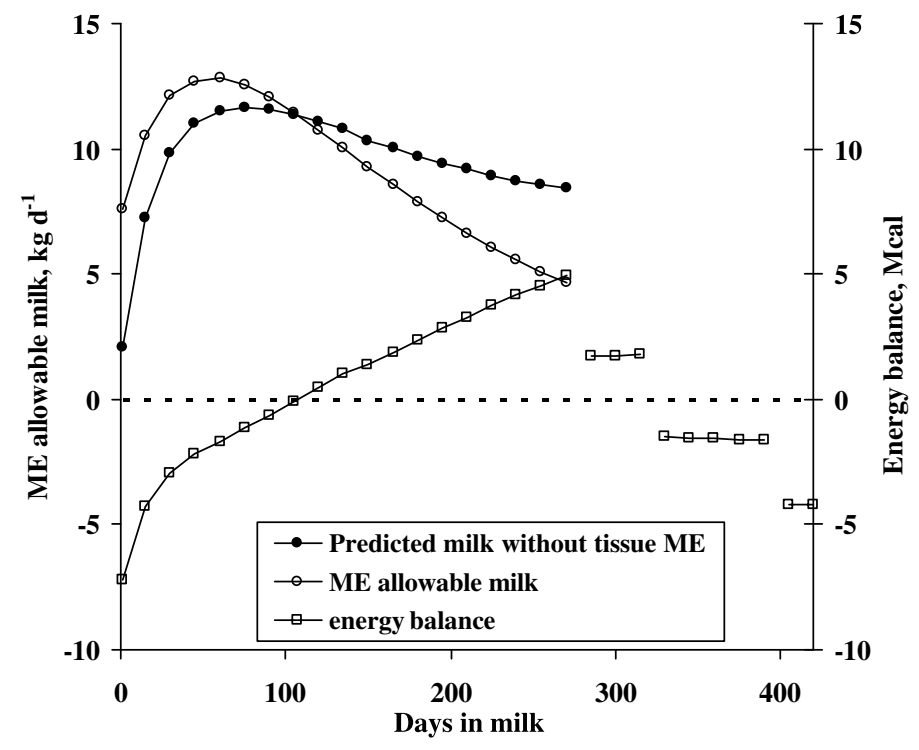

Fig. 3. Comparison of metabolisable energy (ME) allowable milk predictions with and without ME contributions from mobilised body tissue for date of calving to day 115 (period of negative energy balance); and days 130 to 270 of lactation (period of positive energy balance). Body tissue ME balance throughout the calving interval is shown as a reference.

lactation. Mobilised tissues are subsequently repleted in late lactation and the dry period at their corresponding partial efficiencies. Not accounting for these fluxes leads to unrealistic predictions of dietary requirements during early lactation, and at other times when feed supply is inadequate. Nutritional management for grazing cattle includes the use of body tissue reserves when the quality or quantity of feed is inadequate, and by repleting them when dietary quality improves. Supplementation can be used when the combination of body reserves and available feed are insufficient to meet requirements, or the feed supply is inadequate to replenish reserves.

The dynamic application of the CNCPS model predicts tissue balance and fluctuations in body condition that herd managers should anticipate, and uses this information to more accurately estimate animal nutrient requirements and the biological values of feeds in the diet. Management of lactation and reproduction is facilitated by assuring adequate tissue reserves to support these functions in the next production cycle.

Predictions from the dynamic CNCPS model emulate known biological processes and mimic the expected performance (Fig. 2) in a manner that agrees with field observations of dual-purpose cows in the case study region and tropical America (Tables 4 and 5). The results in Fig. 3 indicate the potential of this type of model to enhance management by accounting for the cumulative effects of changes in energy and protein balance over the reproductive cycle of groups of cows that vary in milking potential. A similar approach is being developed to better manage individual cattle growth for the production of beef (Tedeschi et al., 2003). 


\section{Conclusions}

The dynamic application of the CNCPS model described in this study provides a framework for analyzing and integrating the nutritional and productive performance of cows on a dynamic basis throughout a calving interval. This model predicted daily milk production, dietary intake of dry matter, and changes in body weight and body tissue reserves in a manner consistent with biological understanding about nutritional-physiological interactions, published reports, and field observations in dual-purpose cattle systems in the Gulf of Mexico region. Changes in the predicted nutritional status of animals reflect dynamic, cyclic processes of tissue mobilisation and repletion associated with variations in production requirements and nutrient availability during the calving interval.

This model along with accurate inputs is applicable to a range of farm resource scenarios because prediction is based on local animal, production, weather, and feed characteristics. Farm-specific (and group-specific) reference curves that describe expected, or target, performance and nutritional status of management groups of cows throughout a productive cycle would help achieve goals by avoiding errors in feed resource allocation and by assuring adequate body nutrient reserves for subsequent lactation and timely conception.

Sets of animal, nutrition and feed values from predicted reference curves are also valuable for specifying matrices of technical coefficients in multi-period (temporal) bio-economic models (e.g., Nicholson et al., 1994a,b) to evaluate alternative practices, technologies and farming systems with cattle. Technical coefficients from the dynamic application of the CNCPS model would help assure accurate predictions of whole-farm profitability by accounting for important nutritional-physiological dependencies during the production cycle. The ultimate economic implications of inaccurate assessment of nutrient requirements and performance of animals depend on the management response. A dynamic model that includes the relevant biological responses is required to evaluate these options.

\section{References}

Avila, D.A., 1995. Producción con ganado bovino de doble propósito en un sistema modular. Retroalimentación del Modelo GGAVATT al Campo Experimental la Posta. XXIII Día del ganadero del Campo Experimental La Posta. Memoria técnica No. 3, pp. 3-16.

Canfield, R.W., Butler, W.R., 1991. Energy balance, first ovulation and the effects of naloxone on LH secretions in early postpartum dairy cows. Journal of Animal Science 69, 740-746.

Castañeda, M.O.G., Ruiz, L.F., Román, P.H., 1993. Indices productivos de hatos de doble propósito en el estado de Veracruz. Memorias de la Reunion Anual de Investigación Pecuaria, Jalisco, México.

Delgado, C., Rosegrant, M., Steinfeld, H., Ehui, S., Courbois, C., 1999. Livestock to 2020: The next food revolution. International Food Policy Research Institute, Food and Agriculture Organization of the United Nations and the International Livestock Research Institute. Discussion paper 28, Washington, DC, $72 \mathrm{pp}$.

Enriquez, Q.J.F., Kanahan, S.E., 1991. Diagnóstico de la ganadería bovina en el sur de Veracruz. Memorias de la Reunión Nacional de Investigación Pecuaria, Tamaulipas, pp. 141 (Abstract).

Fox, D.G., Tylutki, T.P., 1998. Accounting of the effects of environment on the nutrient requirements of dairy cattle. Journal of Dairy Science 81, 3085-3095. 
Fox, D.G., Sniffen, C.J., O’Connor, J.D., Russell, J.B., Van Soest, P.J., 1992. A net carbohydrate and protein system for evaluating cattle diets: III. Cattle requirements and diet adequacy. Journal of Animal Science 70, 3578-3596.

Fox, D.G., Barry, M.C., Pitt, R.E., Roseler, D.K., Stone, W.C., 1995. Application of the Cornell Net Carbohydrate and Protein Model for cattle consuming forages. Journal of Animal Science 73, 267-277.

Fox, D.G., Juarez, L.F., Pell, A.N., Lanna, D.P., 1997. Predicción de requerimientos nutricionales de los bovinos en condiciones tropicales. XXIII Simposium de Ganadería Tropical: Interacción Nutricion Reproducción en Ganado Bovino, Veracruz, México, pp. 49-69.

Fox, D.G., Tylutki, T.P., Van Amburgh, M.E., Chase, L.E., Pell, A.N., Overton, T.R., Tedeschi, L.O., Rasmussen, C.N., Durban, V.M., 2000. The Net Carbohydrate and Protein System for evaluating herd nutrition and nutrient excretion. CNCPS version 4.0. (C) 2000. Model documentation. Animal Science Mimeo 213. Department of Animal Science, Cornell University, Ithaca, New York.

Fox, D.G., Tedeschi, L.O., Tylutki, T.P., Russell, J.B., Van Amburgh, M.E., Chase, L.E., Pell, A.N., Overton, T.R., 2003. The Cornell Net Carbohydrate and Protein System model for evaluating herd nutrition and nutrient excretion. Animal Feed Science and Technology (in press).

Gonzalez, P.E., 1993. Situación actual y perspectivas de la producción de leche en la ganadería de doble propósito en las regiones tropicales. XVI Simposium de Ganadería Tropical. Secretaría de Agricultura y Recursos Hidráulicos, Veracruz, México.

Juarez, F.I., Fox, D.G., Blake, R.W., Pell, A.N., 1999. Evaluation of tropical grasses for milk production by dual-purpose cows in tropical Mexico. Journal of Dairy Science 82, 2136-2145.

Lanna, D.P.D., Fox, D.G., Boin, C., Traxler, M.J., Barry, M., 1996. Validation of the Cornell Net Carbohydrate and Protein System estimates of nutrient requirements of growing and lactating Zebu germplasm in tropical conditions. Journal of Animal Science 74 (Suppl. 1), 287.

Mulvany, P., 1981. Dairy cow condition scoring. National Institute of Research on Dairying, Paper 4468.

Muñoz, R.M., Cruz, H.A., Menocal, E.S., Vergara, R.B., 1990. El proceso de transferencia de tecnología en la producción de bovinos en el Golfo-sureste de México. Diagnóstico integral de la ganadería bovina en el trópico Mexicano. Secretaría de Agricultura y Recursos Hidráulicos, México, pp. 111-142.

National Research Council, 1989. Nutrient Requirements of Dairy Cattle. Sixth Revised Edition (Update), National Academy Press, Washington, DC.

National Research Council, 2000. Nutrient Requirements for Beef Cattle. Seventh Revised Edition. National Academy Press, Washington, DC.

National Research Council, 2001. Nutrient Requirements of Dairy Cattle. Seventh Revised Edition. National Academy Press, Washington, DC.

Neidhardt, R., Plasse, D., Weiniger, J.H., Verde, O., Beltran, J., Benavides, A., 1979. Milk yield of Brahman cows in a tropical beef production system. Journal of Animal Science 48, 1-6.

Nicholson, C.F., Blake, R.W., Urbina, C.I., Lee, D.R., Fox, D.G., Van Soest, P.J., 1994a. Economic comparison of nutritional management strategies for Venezuelan dual-purpose cattle systems. Journal of Animal Science 72, 1680-1696.

Nicholson, C.F., Lee, D.R., Boisvert, R., Blake, R.W., Urbina, C.I., 1994b. An optimization model of dual purpose cattle production in the humid lowlands of Venezuela. Agricultural Systems 46, 311-334.

Nicholson, C.F., Blake, R.W., Lee, D.R., 1995. Livestock, deforestation, and policy making: Intensification of cattle production systems in central America revisited. Journal of Dairy Science 78, 719-734.

Otto, K.L., Ferguson, J.D., Fox, D.G., Sniffen, C.J., 1991. Relationship between body condition score and composition of ninth to eleventh rib tissue in Holstein dairy cows. Journal of Dairy Science 74, $852-859$.

Reyes, A.A., Blake, R.W., Shumway, C.R., Long, J.T., 1981. Multistage optimization model for dairy production. Journal of Dairy Science 64, 2003-2016.

Rueda, B.L., Blake, R.W., Nicholson, C.F., Fox, D.G., Tedeschi, L.O., Pell, A.N., Fernandes, E.C.M., Valentim, J.F., da Costa, J., 2003. Production and economic potentials of cattle in pasture-based systems of the western Amazon region of Brazil. Journal of Animal Science (in press).

Ruiz, R., Tedeschi, L.O., Marini, J.C., Fox, D.G., Pell, A.N., Jarvis, G., Russell, J.B., 2002. The effect of a ruminal nitrogen $(\mathrm{N})$ deficiency in dairy cows: Evaluation of the Cornell Net Carbohydrate and Protein System ruminal N deficiency adjustment. Journal of Dairy Science 85, 2986-2999. 
Russell, J.B., O’Connor, J.D., Fox, D.G., Van Soest, P.J., Sniffen, C.J., 1992. A Net carbohydrate and protein system for evaluating cattle Diets: I. Ruminal fermentation. Journal of Animal Science 70, 3551-3561.

Sere, C.,Vaccaro, L., 1985. Milk production from dual-purpose systems in tropical Latin America. In: Smith, A.J. (Ed.), Proceedings of Milk Production in Developing Countries. Center for Tropical Veterinary Medicine, University of Edinburgh, Scotland.

Sniffen, C.J., O'Connor, J.D., Fox, D.G., Van Soest, P.J., Russell, J.B., 1992. A net carbohydrate and protein System for evaluating cattle diets: II. Carbohydrate and protein availability. Journal of Animal Science 70, 3562-3577.

Tedeschi, L.O., Fox, D.G., Pell, A.N., Lanna, D., Boin, C., 2002a. Development and evaluation of a tropical feed library for the Cornell Net Carbohydrate and Protein System model. Scientia Agricola 59 (1), 1-18.

Tedeschi, L.O., Boin, C., Fox, D.G., Leme, P.R., Alleoni, G.F., Lanna, D.P.D., 2002b. Energy requirement for maintenance and growth of Nellore bulls and steers fed high-forage diets. Journal of Animal Science. 80, 1671-1682.

Tedeschi, L.O., Fox, D.G., Guiroy, P.J., 2003. A decision support system to improve individual cattle management. 1. A mechanistic, dynamic model for animal growth. Agricultural Systems, doi:10.1016/ S0308-521X(03)00070-2.

Traxler, M.L., 1997. Predicting the effect of lignin on the extent of digestion and the evaluation of alternative intake models for lactating cows consuming high NDF forages. Ph.D. Thesis, Cornell University, Ithaca, New York, 145 pp.

Ventura, S.M., Ozuna, B.D., 1995. Alternativas nutricionales para ganado bovino durante la época seca. In: Madrid-Bury, N., Soto, E. (Eds.), Manejo de la ganaderia mestiza de doble propósito. Belloso, pp. 6-24.

Villa-Godoy, A., Arreguin, A.A., 1993. Tecnología disponible y principales líneas de investigación para resolver el anestro posparto en vacas de doble propósito. XVI Simposium de ganadería tropical. IV Ciclo de Conferencias Sobre Bovinos de Doble Propósito. Secretaría de Agricultura y Recursos Hidráulicos. Veracruz, México.

Williams, C.B., Oltenacu, P.A., Sniffen, C.J., 1989. Refinements in determining the energy value of body tissue reserves and tissue gains from growth. Journal of Dairy Science 72, 264-269. 